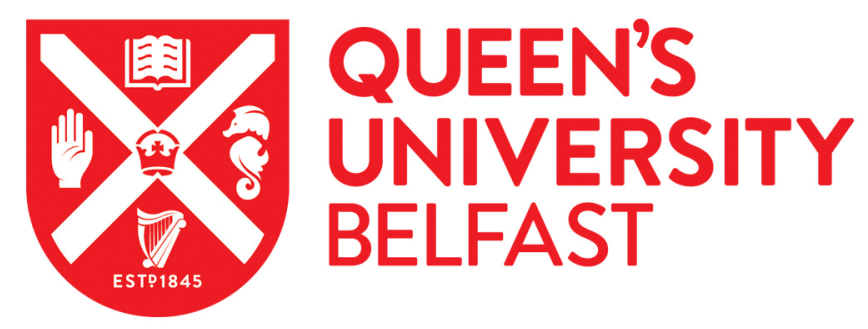

\title{
The arbuscular mycorrhizal fungus Glomus mosseae can enhance arsenic tolerance in Medicago truncatula by increasing plant phosphorus status and restricting arsenate uptake
}

Xu, P. L., Christie, P., Liu, Y., Zhang, Z. L., \& Li, X. L. (2008). The arbuscular mycorrhizal fungus Glomus mosseae can enhance arsenic tolerance in Medicago truncatula by increasing plant phosphorus status and restricting arsenate uptake. Environmental Pollution, 156(1), 215-220.

https://doi.org/10.1016/j.envpol.2008.01.003

\section{Published in:}

Environmental Pollution

Queen's University Belfast - Research Portal:

Link to publication record in Queen's University Belfast Research Portal

\section{General rights}

Copyright for the publications made accessible via the Queen's University Belfast Research Portal is retained by the author(s) and / or other copyright owners and it is a condition of accessing these publications that users recognise and abide by the legal requirements associated with these rights.

Take down policy

The Research Portal is Queen's institutional repository that provides access to Queen's research output. Every effort has been made to ensure that content in the Research Portal does not infringe any person's rights, or applicable UK laws. If you discover content in the Research Portal that you believe breaches copyright or violates any law, please contact openaccess@qub.ac.uk. 


\title{
The arbuscular mycorrhizal fungus Glomus mosseae can enhance arsenic tolerance in Medicago truncatula by increasing plant phosphorus status and restricting arsenate uptake
}

\author{
Pengliang $\mathrm{Xu}^{\mathrm{a}}$, Peter Christie ${ }^{\mathrm{a}, \mathrm{b}}$, Yu Liu ${ }^{\mathrm{a}}$, Junling Zhang ${ }^{\mathrm{a}, *}$, Xiaolin $\mathrm{Li}^{\mathrm{a}}$ \\ ${ }^{a}$ Key Laboratory of Plant-Soil Interactions, Ministry of Education, College of Resources and Environmental Sciences, \\ China Agricultural University, Beijing 100094, China \\ b Agricultural and Environmental Science Department, Queen's University Belfast, Belfast BT9 5PX, UK
}

Received 27 April 2007; received in revised form 11 December 2007; accepted 5 January 2008

G. mosseae was more tolerant than M. truncatula to As and may have conferred enhanced host tolerance by restricting root As uptake and enhancing $P$ nutrition.

\begin{abstract}
A pot experiment examined the biomass and As uptake of Medicago truncatula colonized by the arbuscular mycorrhizal (AM) fungus Glomus mosseae in low-P soil experimentally contaminated with different levels of arsenate. The biomass of G. mosseae external mycelium was unaffected by the highest addition level of As studied $\left(200 \mathrm{mg} \mathrm{kg}^{-1}\right)$ but shoot and root biomass declined in both mycorrhizal and nonmycorrhizal plants, indicating that the AM fungus was more tolerant than $M$. truncatula to arsenate. Mycorrhizal inoculation increased shoot and root dry weights by enhancing host plant $\mathrm{P}$ nutrition and lowering shoot and root As concentrations compared with uninoculated plants. The AM fungus may have been highly tolerant to As and conferred enhanced tolerance to arsenate on the host plant by enhancing P nutrition and restricting root As uptake.
\end{abstract}

(C) 2008 Elsevier Ltd. All rights reserved.

Keywords: Arbuscular mycorrhiza; Arsenate; Glomus mosseae; Medicago truncatula; Phosphate uptake

\section{Introduction}

Plants growing on arsenic polluted soils tend to be mycorrhizal (Meharg and Hartley-Whitaker, 2002) and mycorrhizal fungi may therefore be important in re-vegetation or phytostabilization. Hymenoscyphus ericae, an ericoid mycorrhizal fungus, has co-evolved with its host plant, Calluna vulgaris, to resist As toxicity (Sharples et al., 2000a,b,2001). Al Agely et al. (2005) reported a pot experiment in which arbuscular mycorrhizal fungi (AMF) increased As uptake by Chinese

\footnotetext{
* Corresponding author: Key Laboratory of Plant-Soil Interactions, Ministry of Education, College of Resources and Environmental Sciences, China Agricultural University, Yuanmingyuan West Road No. 2, Beijing 100094, China. Tel.: +86106273 3406; fax: +861062731016.

E-mail address: junlingz@cau.edu.cn (J. Zhang).
}

brake fern (Pteris vittata), suggesting that plant mycorrhizal status should be considered for effective phytoremediation.

It is well established that AMF can enhance host plant $\mathrm{P}$ uptake under limited P availability (Smith and Read, 1997). Arsenate and phosphate show similar behaviour, e.g. both compete for the same sorption sites on soil particles (Adriano, 2001). Uptake of As and $P$ by plants and microorganisms is shown to be mediated by the same transporters (Asher and Reay, 1979; Willsky and Malamy, 1980a,b; Meharg and Macnair, 1990,1992; Bun-ya et al., 1996; Rosen, 2002), and thus enhanced plant acquisition of $\mathrm{P}$ may also lead to enhanced acquisition of As. Gonzalez-Chavez et al. (2002) reported enhanced arsenate resistance of both tolerant and nontolerant plants colonized by AMF associated with suppression of high-affinity arsenate/phosphate transporters and decreasing arsenate uptake. Ahmed et al. (2006) showed that inoculation 
with G. mosseae lowered As concentrations in shoots and roots of lentil and the fungus may have promoted $\mathrm{P}$ uptake but excluded arsenic. The mechanisms by which AM fungi influence the relationship between arsenate resistance and arsenate/phosphate uptake are yet to be elucidated (Meharg and Hartley-Whitaker, 2002). Here, we attempted to acquire more information on the possible enhancement of plant arsenate tolerance by AM colonization.

\section{Materials and methods}

\subsection{Plants, AM fungus and soil}

Seeds of Medicago truncatula cv. Paraggio were surface sterilized by immersion in $30 \% \mathrm{v} / \mathrm{v} \mathrm{H}_{2} \mathrm{O}_{2}$ for $10 \mathrm{~min}$, rinsed with deionized water three times and germinated on moist filter paper at $20^{\circ} \mathrm{C}$. After two days, seedlings with radicles $\sim 1-2 \mathrm{~mm}$ long were transplanted into 10 -cm-diameter pots. Glomus mosseae BEG 167 was prepared by growing maize (Zea mays L.) and red clover (Trifolium pratense L.) in a low-P soil. The soil, a sandy clay loam with low Olsen P from the A horizon at Tangshan, Hebei province, north China, had the following properties: $\mathrm{pH}$ (in $\mathrm{H}_{2} \mathrm{O}$ ) 7.4, 8.24 $\mathrm{g}$ organic $\mathrm{C} \mathrm{kg}^{-1}$,

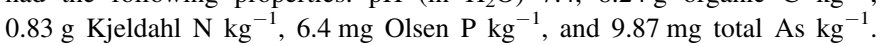
Soil was sieved $(<2 \mathrm{~mm})$, autoclaved at $121^{\circ} \mathrm{C}$ for $2 \mathrm{~h}$ and then air-dried before use. The dry soil was amended with $200 \mathrm{mg} \mathrm{N} \mathrm{kg}^{-1}$ (as $\mathrm{NH}_{4} \mathrm{NO}_{3}$ ) and $171 \mathrm{mg} \mathrm{K} \mathrm{kg}^{-1}$ (as $\left.\mathrm{K}_{2} \mathrm{SO}_{4}\right)$.

\subsection{Experimental setup}

The experimental treatments consisted of five addition levels of As $(0,10$, 50,100 and $200 \mathrm{mg} \mathrm{kg}^{-1}$ ) as $\mathrm{Na}_{3} \mathrm{AsO}_{4} \cdot 12 \mathrm{H}_{2} \mathrm{O}$ and $\mathrm{As}$ was applied to the soil in aqueous solution. Soils were then maintained in plastic bags to equilibrate for three weeks prior to seedling transplantation. Plants were inoculated with G. mosseae-colonized roots and spores from pot culture and uninoculated controls received filtered inoculum washings. There were four replicate pots per treatment in a randomized block design, giving a total of 40 pots. Each pot received $800 \mathrm{~g}$ soil, $100 \mathrm{~g}$ inoculum (inoculated treatment) or autoclaved inoculum (uninoculated treatment) was placed on the soil surface, and a further $100 \mathrm{~g}$ soil was placed over the inoculum. Eight seedlings were transplanted in each pot and sand $\left(120 \mathrm{~g} \mathrm{pot}^{-1}\right)$ was placed on the soil surface. The experiment was conducted from 6 December 2003 to 11 February 2004 in a glasshouse in Beijing at $22-28^{\circ} \mathrm{C}$ without supplementary illumination. Deionized water was added by weighing when water loss was approximately $10 \%$ of total pot weight.

\subsection{Plant harvest and chemical analysis}

Shoots and roots were harvested separately after two months' growth. Root systems were collected by hand and washed carefully with tap water and deionized water. Nodules were occasionally found on both mycorrhizal and nonmycorrhizal plant roots but their frequency of occurrence was very low $(<5 \%)$. A randomly-selected portion of fresh roots from each pot was stained with Trypan blue (Phillips and Hayman, 1970) and both root length and the percentage of root length colonized were determined using the grid-line intersect method of Giovannetti and Mosse (1980). Shoots and roots were weighed after oven drying at $70{ }^{\circ} \mathrm{C}$ for $72 \mathrm{~h}$ and ground sub-samples $(0.1-0.2 \mathrm{~g}$ ) were digested with $5 \mathrm{ml}$ 4:1 (v/v) $\mathrm{HNO}_{3} / \mathrm{HClO}_{4}$ for $\mathrm{P}$ and As analysis. Phosphorus was determined by the molybdenum blue method (Allen, 1989) and As using a Model AFS-920 Atomic Fluorescence Spectrometer (Beijing Titan Instruments Co. Ltd.). The extraradical mycelium was extracted from three replicate $\sim 7$-g sub-samples of soil from each pot using the aqueous membrane filtration technique (Boddington et al., 1999) and hyphal length was estimated using a modified membrane filter technique (Jakobsen et al., 1992).

\subsection{Statistical analysis}

Data were tested for normality using the Shapiro-Wilk test and the significance of treatment effects was analyzed by one- or two-way analysis
Table 1

Proportion of root length colonized, root length, AMF hyphal density in soil and AMF hyphal length per unit root length of $M$. truncatula colonized by G. mosseae

\begin{tabular}{lllll}
\hline $\begin{array}{l}\text { As addition } \\
\text { level } \\
\left(\mathrm{mg} \mathrm{kg}^{-1}\right)\end{array}$ & $\begin{array}{l}\text { Colonization } \\
(\%)\end{array}$ & $\begin{array}{l}\text { Root length } \\
\left(\mathrm{m} \mathrm{pot}^{-1}\right)\end{array}$ & $\begin{array}{l}\text { AMF hyphal } \\
\text { density in } \\
\text { soil }\left(\mathrm{m} \mathrm{g}^{-1}\right)\end{array}$ & $\begin{array}{l}\text { AMF hyphal } \\
\text { length per unit } \\
\text { root length } \\
\left(\mathrm{m} \mathrm{m}^{-1}\right)\end{array}$ \\
\hline 0 & $55.0 \pm 6.7$ & $85.2 \pm 7.0 \mathrm{a}$ & $0.397 \pm 0.229$ & $4.14 \pm 2.45 \mathrm{~b}$ \\
10 & $59.7 \pm 8.4$ & $98.8 \pm 25.9 \mathrm{a}$ & $0.753 \pm 0.276$ & $7.99 \pm 3.01 \mathrm{~b}$ \\
50 & $50.6 \pm 11.3$ & $92.8 \pm 11.3 \mathrm{a}$ & $0.745 \pm 0.210$ & $7.95 \pm 1.74 \mathrm{~b}$ \\
100 & $53.1 \pm 5.8$ & $77.2 \pm 6.8 \mathrm{ab}$ & $0.805 \pm 0.389$ & $10.40 \pm 5.06 \mathrm{~b}$ \\
200 & $46.4 \pm 17.7$ & $\begin{array}{l}26.4 \pm 5.7 \mathrm{~b} \\
P<0.001\end{array}$ & $0.720 \pm 0.192$ & $27.89 \pm 8.67 \mathrm{a}$ \\
Significance $^{\mathrm{a}}$ & $\mathrm{ns}$ & $P<0.001$ & $P<0.001$ \\
\hline
\end{tabular}

Data are presented as mean values $\pm \mathrm{SD}(n=4)$ and have been analyzed by one-way analysis of variance. Means followed by the same letter within columns are not significantly different by Duncan's multiple range test at the $5 \%$ level.

${ }^{\mathrm{a}}$ By one-way analysis of variance; ns, not significant.

of variance using the SAS software package (SAS Institute Inc., Cary, NC, USA).

\section{Results and discussion}

Arsenate addition did not inhibit AM colonization of $M$. truncatula roots and the mean percentage of root length colonized was $53.0 \%$ whilst no colonization was observed in uninoculated plants (Table 1). Root length decreased markedly at the highest As application rate $\left(200 \mathrm{mg} \mathrm{kg}^{-1}\right)$ but the hyphal density of $G$. mosseae showed no corresponding change. Consequently, AM hyphal length per unit root length increased substantially at this As level. In contrast, shoot and root dry matter biomass of $M$. truncatula decreased when the As addition level was $>10 \mathrm{mg} \mathrm{kg}^{-1}$ (Fig. 1) but root

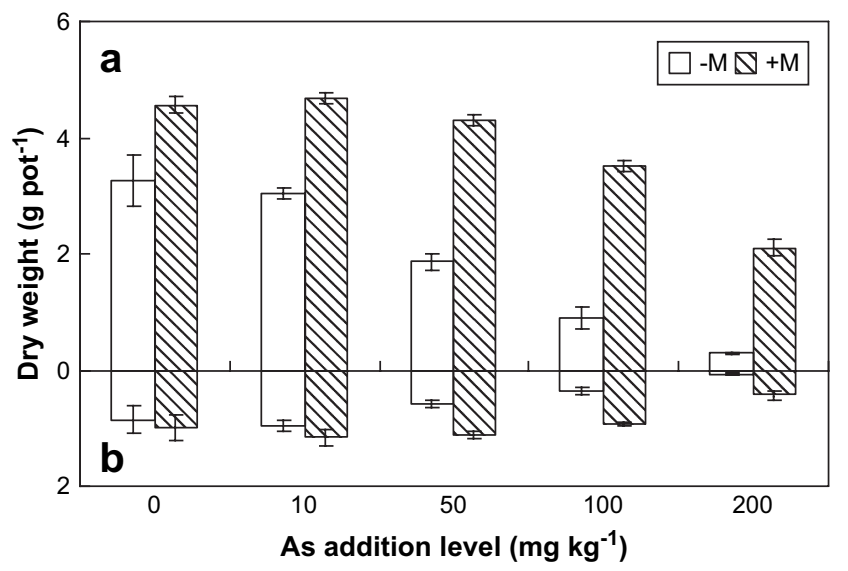

\begin{tabular}{|l|c|c|}
\hline Significance due to & Shoots & Roots \\
\hline Inoculation & $P<0.001$ & $P<0.001$ \\
\hline As level & $P<0.001$ & $P<0.001$ \\
\hline Interaction & $P<0.001$ & $P<0.001$ \\
\hline
\end{tabular}

Fig. 1. Mean shoot (a) and root (b) dry weight of non-mycorrhizal and mycorrhizal M. truncatula colonized by $G$. mosseae. Error bars: \pm SD. Data have been analyzed by two-way analysis of variance. 
colonization and hyphal density were unaffected even at an As application rate of $200 \mathrm{mg} \mathrm{kg}^{-1}$ (Table 1), indicating that the AM fungus was more tolerant to arsenate than was its host plant. Shoot and root dry weights of mycorrhizal plants were significantly higher than those of non-mycorrhizal controls at all As additional levels $(P<0.001)$. At $200 \mathrm{mg} \mathrm{kg}^{-1}$ added As, growth of non-mycorrhizal plants was poor but all plants survived. Growth of mycorrhizal plants was much greater than that of the non-mycorrhizal controls (Fig. 1). Our results are in agreement with other studies which have also reported higher tolerance of AMF to As as indicated by enhanced growth of mycorrhizal plants compared with non-mycorrhizal plants (Gonzalez-Chavez et al., 2002; Ahmed et al., 2006; Leung et al., 2006; Trotta et al., 2006; Chen et al., 2007).

Adding arsenate to the soil increased the As concentrations in shoots and roots of both mycorrhizal and nonmycorhizal plants and the trend was less pronounced in plants inoculated with G. mosseae (Fig. 2). At and above
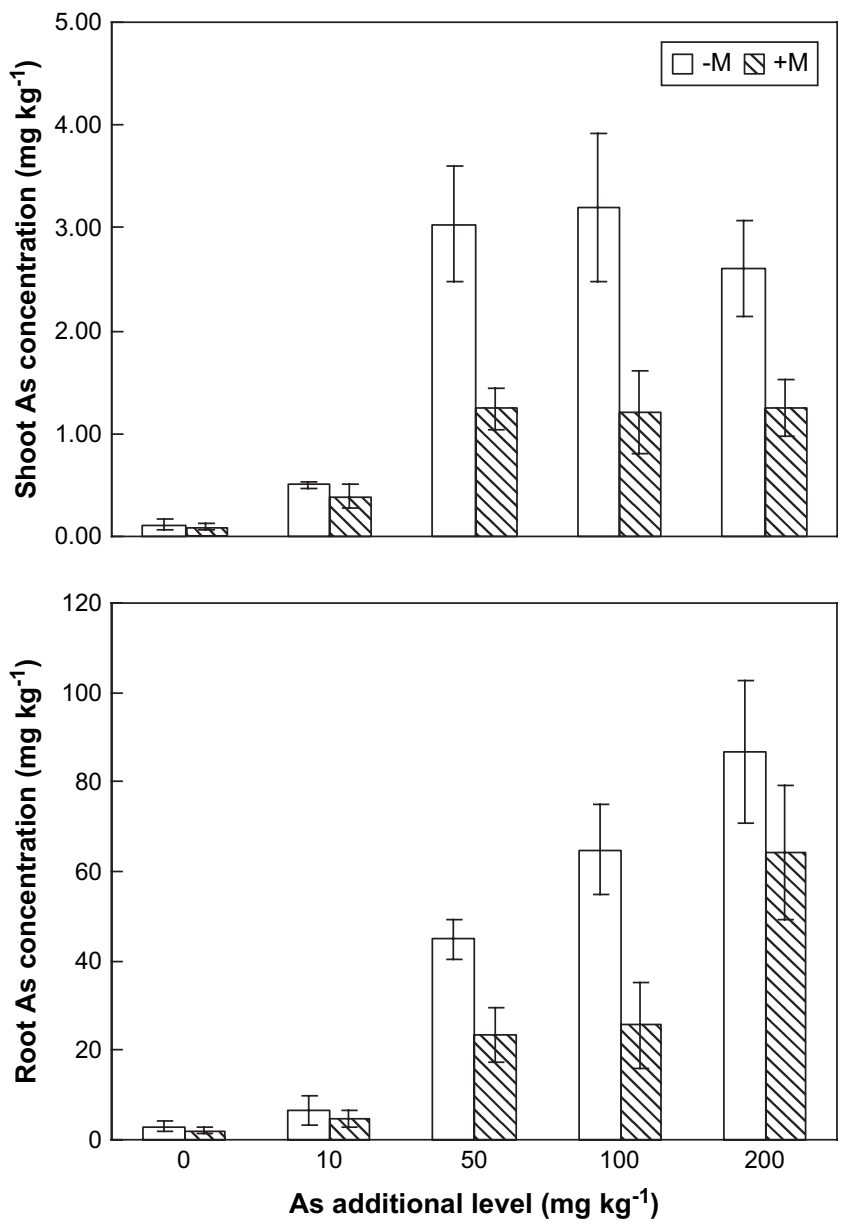

\begin{tabular}{|l|c|c|}
\hline Significance due to & Shoots & Roots \\
\hline Inoculation & $P<0.001$ & $P<0.001$ \\
\hline As level & $P<0.001$ & $P<0.001$ \\
\hline Interaction & $P<0.001$ & $P<0.001$ \\
\hline
\end{tabular}

Fig. 2. Mean shoot and root As concentrations of non-mycorrhizal and mycorrhizal M. truncatula colonized by $G$. mosseae. Error bars: \pm SD. Data have been analyzed by two-way analysis of variance.
$50 \mathrm{mg} \mathrm{kg}^{-1}$ added As, shoot As concentrations in both mycorrhizal and non-mycorrhizal plants remained constant but root As concentrations were elevated with increasing added As (Fig. 2). Root As concentrations were much higher than shoot concentrations regardless of plant mycorrhizal status. Our results support the conclusion that limiting the translocation of arsenate from roots to shoots is an effective mechanism involved in plant As tolerance (Meharg and Macnair, 1991). The substantial accumulation of As in roots may be phytotoxic because arsenate, an analogue of phosphate, disturbs the metabolism of phosphorus, for instance by interfering with ATP synthesis by forming unstable ADP-As. Increasing cytoplasmic P may also enable phosphate to compete more effectively with arsenate to decrease arsenate toxicity (Meharg, 1994). To relieve stress from root As accumulation, non-mycorrhizal plants maintain root $\mathrm{P}$ concentrations at the cost of decreasing shoot $\mathrm{P}$ concentrations (Fig. 3), whereas mycorrhizal plants readily
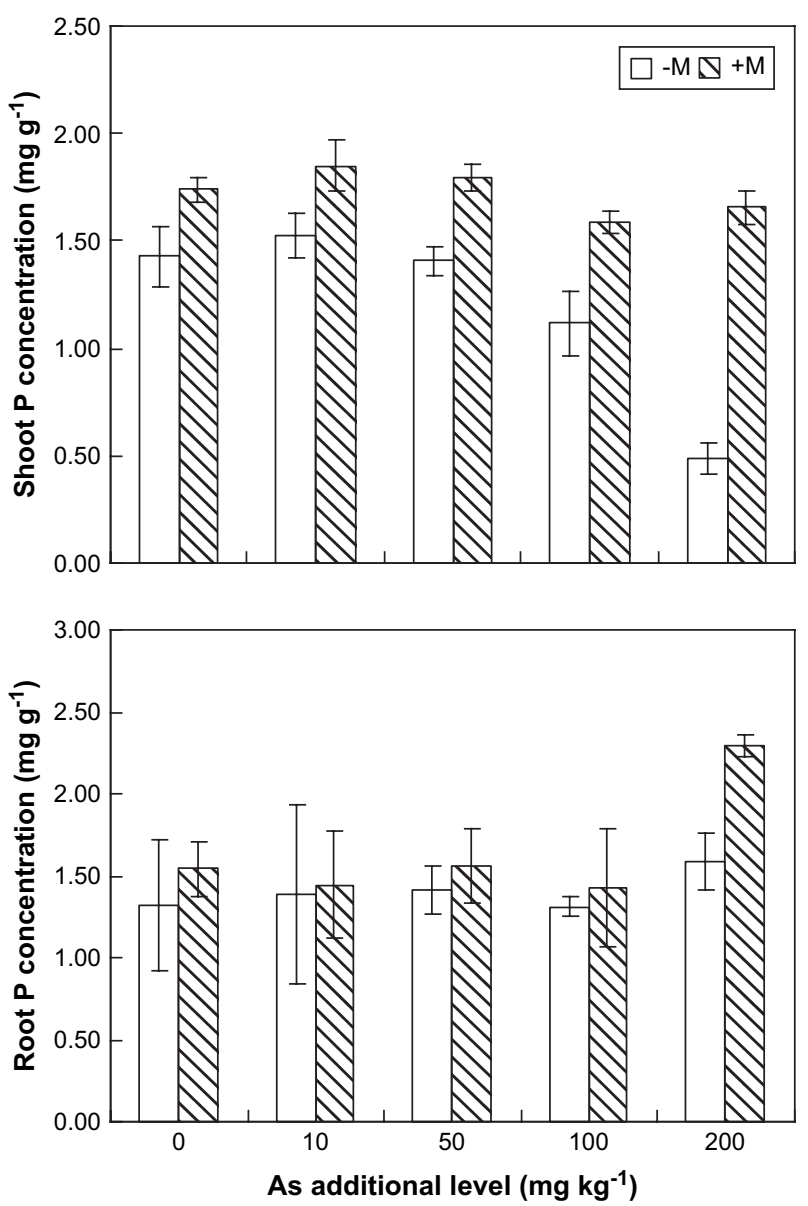

\begin{tabular}{|l|c|c|}
\hline Significance due to & Shoots & Roots \\
\hline Inoculation & $P<0.001$ & $P<0.05$ \\
\hline As level & $P<0.001$ & $P<0.01$ \\
\hline Interaction & $P<0.001$ & ns \\
\hline
\end{tabular}

Fig. 3. Mean shoot and root $\mathrm{P}$ concentrations of non-mycorrhizal and mycorrhizal M. truncatula colonized by $G$. mosseae. Error bars: \pm SD. Data have been analyzed by two-way analysis of variance. 
maintain root $\mathrm{P}$ concentrations without reducing shoot $\mathrm{P}$ concentrations.

Improving plant $\mathrm{P}$ nutrition is regarded as an important mechanism by which mycorrhizal plants withstand high As concentrations (Ahmed et al., 2006; Leung et al., 2006; Trotta et al., 2006; Ultra et al., 2007). Our results agree with this. The AMF enhanced shoot $\mathrm{P}$ concentrations, shoot and root $\mathrm{P}$ contents and plant total $\mathrm{P}$ contents at all As addition levels (Table 2). At the highest (200 $\mathrm{mg} \mathrm{kg}^{-1}$ ) As addition level the mean shoot and root $\mathrm{P}$ concentrations of mycorrhizal plants were 3.4 and 1.4 times higher than those of non-mycorrhizal controls and the corresponding values for shoot and root $\mathrm{P}$ contents were 25 and 8 times. In contrast, shoot and root As concentrations in mycorrhizal plants in soil amended with $>10 \mathrm{mg} \mathrm{As} \mathrm{kg}^{-1}$ tended to be only half of the values for corresponding non-mycorrhizal controls (Fig. 2). In addition, specific shoot $\mathrm{P}$ uptake of mycorrhizal plants was significantly higher than that of non-mycorrhizal controls at all As addition levels but As showed the opposite trend (Table 3). Specific $\mathrm{P}$ uptake of non-mycorrhizal plants decreased with increasing As addition level but that of mycorrhizal plants remained relatively stable. Consequently, AM colonization increased the shoot and root P:As content ratio, especially at higher soil As levels (Table 2). It can be inferred that the AM fungus can enhance host plant $\mathrm{P}$ nutrition while
Table 3

Specific $\mathrm{P}$ and As uptake of shoots of non-mycorrhizal and mycorrhizal $M$. truncatula

\begin{tabular}{lllll}
\hline $\begin{array}{l}\text { Added As } \\
\left(\mathrm{mg} \mathrm{kg}^{-1}\right)\end{array}$ & $\begin{array}{l}\text { Specific P uptake } \\
\left(\mathrm{mg} \mathrm{g}^{-1} \text { root }\right)\end{array}$ & \multicolumn{2}{l}{$\begin{array}{l}\text { Specific As uptake } \\
\left(\mu \mathrm{g} \mathrm{g}^{-1} \text { root }\right)\end{array}$} \\
\cline { 2 - 3 } \cline { 5 - 6 } & $\begin{array}{l}\text { Non- } \\
\text { mycorrhizal }\end{array}$ & Mycorrhizal & $\begin{array}{l}\text { Non- } \\
\text { mycorrhizal }\end{array}$ & Mycorrhizal \\
& $6.54 \pm 1.66 \mathrm{a}$ & $9.86 \pm 1.79 \mathrm{a}$ & $4.11 \pm 0.49 \mathrm{~d}$ & $2.27 \pm 0.81 \mathrm{c}$ \\
& $6.18 \pm 0.48 \mathrm{a}$ & $9.01 \pm 1.56 \mathrm{ab}$ & $8.23 \pm 3.34 \mathrm{~d}$ & $6.21 \pm 2.36 \mathrm{c}$ \\
10 & $5.99 \pm 0.75 \mathrm{a}$ & $8.47 \pm 0.71 \mathrm{ab}$ & $54.54 \pm 5.60 \mathrm{c}$ & $28.14 \pm 5.77 \mathrm{~b}$ \\
50 & $4.08 \pm 0.68 \mathrm{~b}$ & $7.45 \pm 0.22 \mathrm{~b}$ & $72.69 \pm 9.95 \mathrm{~b}$ & $30.16 \pm 8.34 \mathrm{~b}$ \\
100 & $3.54 \pm 0.15 \mathrm{~b}$ & $10.45 \pm 1.80 \mathrm{a}$ & $97.33 \pm 15.32 \mathrm{a}$ & $70.37 \pm 13.81 \mathrm{a}$ \\
200 & & $P<0.001$ & \\
Inoculation & $P<0.001$ & & $P<0.001$ & \\
As level & $P<0.01$ & & $P<0.001$ & \\
Interaction & $P<0.01$ & & &
\end{tabular}

Data are presented as mean values \pm SD $(n=4)$ and have been analyzed by two-way analysis of variance. Means followed by the same letter within columns are not significantly different by Duncan's multiple range test at the $5 \%$ level.

suppressing plant As uptake, and this agrees with a recent study by Chen et al. (2007). Plants take up arsenate via the phosphate uptake system (Asher and Reay, 1979; Meharg and Macnair, 1990, 1992) and the suppression of high affinity $\mathrm{P}$ uptake therefore assists plants to enhance arsenate tolerance (Meharg and Macnair, 1992). Interestingly, AMF can

Table 2

$\mathrm{P}$ and As contents and molar P/As content ratios of non-mycorrhizal and mycorrhizal M. truncatula colonized by G. mosseae

\begin{tabular}{|c|c|c|c|c|c|c|}
\hline \multirow[t]{2}{*}{ Added As (mg kg $\left.{ }^{-1}\right)$} & \multicolumn{2}{|c|}{$\mathrm{P}$ content $\left(\mathrm{mg} \operatorname{pot}^{-1}\right)$} & \multicolumn{2}{|c|}{ As content $\left(\mu \mathrm{g} \mathrm{pot}^{-1}\right)$} & \multicolumn{2}{|c|}{$\mathrm{P} / \mathrm{As}$ content ratio (mol P/mmol As) } \\
\hline & Non-mycorrhizal & Mycorrhizal & Non-mycorrhizal & Mycorrhizal & Non-mycorrhizal & Mycorrhizal \\
\hline \multicolumn{7}{|l|}{ Shoots } \\
\hline 0 & $4.77 \pm 0.13 \mathrm{a}$ & $7.94 \pm 0.16 b$ & $0.38 \pm 0.13 d$ & $0.42 \pm 0.12 \mathrm{c}$ & $33.07 \pm 12.17 \mathrm{a}$ & $49.11 \pm 15.26 \mathrm{a}$ \\
\hline 10 & $4.62 \pm 0.20 \mathrm{a}$ & $8.63 \pm 0.40 \mathrm{a}$ & $1.53 \pm 0.11 \mathrm{c}$ & $1.82 \pm 0.51 b$ & $7.34 \pm 0.81 b$ & $11.99 \pm 2.52 b$ \\
\hline 50 & $2.61 \pm 0.23 b$ & $7.72 \pm 0.34 b$ & $5.60 \pm 0.82 \mathrm{a}$ & $5.33 \pm 0.85 a$ & $1.16 \pm 0.27 b$ & $3.56 \pm 0.55 b$ \\
\hline 100 & $1.01 \pm 0.30 \mathrm{c}$ & $5.55 \pm 0.06 \mathrm{c}$ & $2.81 \pm 0.67 \mathrm{~b}$ & $4.22 \pm 1.39 \mathrm{a}$ & $0.88 \pm 0.22 b$ & $3.40 \pm 0.91 b$ \\
\hline 200 & $0.14 \pm 0.03 \mathrm{~d}$ & $3.50 \pm 0.36 \mathrm{~d}$ & $0.76 \pm 0.12 \mathrm{~d}$ & $2.66 \pm 0.74 b$ & $0.47 \pm 0.16 b$ & $3.31 \pm 0.64 b$ \\
\hline Inoculation & $P<0.001$ & & $P<0.01$ & & $P<0.01$ & \\
\hline As level & $P<0.001$ & & $P<0.001$ & & $P<0.001$ & \\
\hline Interaction & $P<0.001$ & & $P<0.05$ & & $\mathrm{~ns}$ & \\
\hline \multicolumn{7}{|l|}{ Roots } \\
\hline 0 & $1.12 \pm 0.25 \mathrm{ab}$ & $1.52 \pm 0.22 \mathrm{ab}$ & $3.06 \pm 1.26 b$ & $2.03 \pm 0.65 b$ & $0.98 \pm 0.36 \mathrm{a}$ & $1.96 \pm 0.69 \mathrm{a}$ \\
\hline 10 & $1.36 \pm 0.61 \mathrm{a}$ & $1.64 \pm 0.19 \mathrm{ab}$ & $6.50 \pm 3.54 b$ & $5.18 \pm 1.73 b$ & $0.56 \pm 0.20 \mathrm{~b}$ & $0.85 \pm 0.36 \mathrm{~b}$ \\
\hline 50 & $0.82 \pm 0.13 b c$ & $1.74 \pm 0.26 \mathrm{a}$ & $25.98 \pm 3.86 a$ & $26.01 \pm 5.61 \mathrm{a}$ & $0.08 \pm 0.01 b$ & $0.17 \pm 0.04 \mathrm{c}$ \\
\hline 100 & $0.48 \pm 0.10 \mathrm{~cd}$ & $1.33 \pm 0.36 b c$ & $23.08 \pm 2.09 a$ & $23.75 \pm 9.29 \mathrm{a}$ & $0.05 \pm 0.01 b$ & $0.14 \pm 0.03 \mathrm{c}$ \\
\hline 200 & $0.12 \pm 0.03 d$ & $1.01 \pm 0.18 \mathrm{c}$ & $6.47 \pm 2.19 b$ & $28.18 \pm 7.41 \mathrm{a}$ & $0.04 \pm 0.01 b$ & $0.09 \pm 0.02 \mathrm{c}$ \\
\hline Inoculation & $P<0.001$ & & $P<0.05$ & & $P<0.01$ & \\
\hline As level & $P<0.001$ & & $P<0.001$ & & $P<0.001$ & \\
\hline Interaction & $\mathrm{ns}$ & & $P<0.001$ & & $P<0.05$ & \\
\hline \multicolumn{7}{|l|}{ Total } \\
\hline 0 & $5.95 \pm 0.25 \mathrm{a}$ & $9.46 \pm 0.32 b$ & $3.44 \pm 1.36 \mathrm{~d}$ & $2.45 \pm 0.72 b$ & $4.55 \pm 1.54 \mathrm{a}$ & $10.14 \pm 3.65 \mathrm{a}$ \\
\hline 10 & $5.98 \pm 0.69 a$ & $10.27 \pm 0.58 \mathrm{a}$ & $8.04 \pm 3.53 c$ & $7.00 \pm 2.04 b$ & $2.06 \pm 0.87 b$ & $3.81 \pm 1.28 \mathrm{~b}$ \\
\hline 50 & $3.43 \pm 0.18 b$ & $9.46 \pm 0.60 \mathrm{~b}$ & $31.58 \pm 4.63 \mathrm{a}$ & $31.34 \pm 5.09 \mathrm{a}$ & $0.27 \pm 0.05 b$ & $0.74 \pm 0.11 \mathrm{c}$ \\
\hline 100 & $1.49 \pm 0.39 \mathrm{c}$ & $6.88 \pm 0.33 c$ & $25.88 \pm 2.12 b$ & $27.97 \pm 8.26 \mathrm{a}$ & $0.14 \pm 0.03 b$ & $0.64 \pm 0.20 \mathrm{c}$ \\
\hline 200 & $0.26 \pm 0.05 \mathrm{~d}$ & $4.51 \pm 0.44 d$ & $7.23 \pm 2.25 \mathrm{~cd}$ & $30.84 \pm 7.17 \mathrm{a}$ & $0.09 \pm 0.02 b$ & $0.37 \pm 0.11 \mathrm{c}$ \\
\hline Inoculation & $P<0.001$ & & $P<0.01$ & & $P<0.001$ & \\
\hline As level & $P<0.001$ & & $P<0.001$ & & $P<0.001$ & \\
\hline Interaction & $P<0.001$ & & $P<0.001$ & & $P<0.01$ & \\
\hline
\end{tabular}

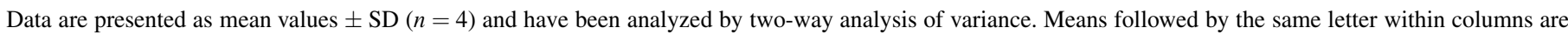
not significantly different by Duncan's multiple range test at the $5 \%$ level. 
downregulate high-affinity phosphate transporters (MtPT1 and MtPT2) which may be responsible for absorption of phosphate from soil by M. truncatula (Liu et al., 1998; Chiou et al., 2001; Burleigh, 2001). Furthermore, studies on the kinetics of phosphate/arsenate uptake have suggested that AMF can downregulate phosphate/arsenate transporters in both arsenate resistant and non-resistant Holcus lanatus (Gonzalez-Chavez et al., 2002). Recent studies have established that the mycorrhizal pathway, in contrast with the direct root uptake pathway, can dominate plant $\mathrm{P}$ uptake, so that most (perhaps almost all) of the plant $\mathrm{P}$ comes from AMF (Smith et al., 2003). This implies that the probability of arsenate entering plants directly through the phosphate uptake system may decrease greatly. Taking together the studies by Burleigh (2001) and Smith et al. (2003) an interesting relationship between the capacities of AMF to provide $\mathrm{P}$ nutrition and downregulate the phosphate transporter can be suggested. Thus, for a particular AMF, the more $\mathrm{P}$ nutrition supplied, the more strongly the transcription of the phosphate transporter may be suppressed. More work is required to clarify the mechanisms by which AMF regulate P-As uptake by plants and enhance plant tolerance to As stress. In a recent study Ultra et al. (2007) reported that AMF seemed to be involved in the transformation of inorganic As into less toxic organic forms which consequently led to decreased As uptake by sunflower plants.

\section{Acknowledgements}

This work was funded by the National Natural Science Foundation of China (Projects 30571105 and 30370818), the British Council (Project DelPHE 1.64) and the '863' Program of the Chinese Science and Technology Department (Project 2001AA247031). We also thank two anonymous reviewers whose helpful suggestions have greatly improved the manuscript.

\section{References}

Adriano, D.C. (Ed.), 2001. Trace Elements in Terrestrial Environments: Biogeochemistry, Bioavailability, and Risks of Metals, second ed. Springer, New York.

Ahmed, F.R.S., Killham, K., Alexander, I., 2006. Influences of arbuscular mycorrhizal fungus Glomus mosseae on growth and nutrition of lentil irrigated with arsenic contaminated water. Plant and Soil 283, $33-41$.

Al Agely, A., Sylvia, D.M., Ma, L.Q., 2005. Mycorrhizae increase arsenic uptake by the hyperaccumulator Chinese brake fern (Pteris vittata L.). Journal of Environmental Quality 34, 2181-2186.

Allen, S.E., 1989. Chemical Analysis of Ecological Materials, second ed. Blackwell Science, Oxford

Asher, C.J., Reay, P.F., 1979. Arsenic uptake by barley seedlings. Australian Journal of Plant Physiology 6, 459-466.

Boddington, C.L., Bassett, E.E., Jakobsen, I., Dodd, J.C., 1999. Comparison of techniques for the extraction and quantification of extra-radical mycelium of arbuscular mycorrhizal fungi in soils. Soil Biology and Biochemistry 31, 479-482.

Bun-ya, M., Shikata, K., Nakade, S., Yompakdee, C., Harashima, S., Oshima, Y., 1996. Two new genes, PHO86 and PHO87, involved in inorganic phosphate uptake in Saccharomyces cerevisiae. Current Genetics 29, 344-351.

Burleigh, S.H., 2001. Relative quantitative RT-PCR to study the expression of plant nutrient transporters in arbuscular mycorrhizas. Plant Science 160, 899-904.

Chen, B.D., Xiao, X.Y., Zhu, Y.G., Smith, F.A., Xie, Z.M., Smith, S.E., 2007. The arbuscular mycorrhizal fungus Glomus mosseae gives contradictory effects on phosphorus and arsenic acquisition by Medicago sativa Linn. Science of the Total Environment 379, $226-234$.

Chiou, T.J., Liu, H., Harrison, M.J., 2001. The spatial expression patterns of a phosphate transporter (MtPT1) from Medicago truncatula indicate a role in phosphate transport at the root/soil interface. Plant Journal 25, 281-293.

Giovannetti, M., Mosse, B., 1980. Evaluation of techniques for measuring vesicular arbuscular mycorrhizal infection in roots. New Phytologist 84, 489-500.

Gonzalez-Chavez, C., Harris, P.J., Dodd, J., Meharg, A.A., 2002. Arbuscular mycorrhizal fungi confer enhanced arsenate resistance on Holcus lanatus. New Phytologist 155, 163-171.

Jakobsen, I., Abbott, L.K., Robson, A.D., 1992. External hyphae of vesiculararbuscular mycorrhizal fungi associated with Trifolium subterraneum L. 1. Spread of hyphae and phosphorus inflow into roots. New Phytologist 120, $371-380$.

Leung, H.M., Ye, Z.H., Wong, M.H., 2006. Interaction of mycorrhizal fungi with Pteris vittata (As hyperaccumulator) in As-contaminated soils. Environmental Pollution 139, 1-8.

Liu, H., Trieu, A.T., Blaylock, L.A., Harrison, M.J., 1998. Cloning and characterization of two phosphate transporters from Medicago truncatula roots: regulation in response to phosphate and to colonization by arbuscular mycorrhizal (AM) fungi. Molecular Plant-Microbe Interactions $11,14-22$.

Meharg, A.A., 1994. Integrated tolerance mechanisms: constitutive and adaptive plant responses to elevated metal concentrations in the environment. Plant, Cell and Environment 17, 989-993.

Meharg, A.A., Hartley-Whitaker, J., 2002. Arsenic uptake and metabolism in arsenic resistant and nonresistant plant species. New Phytologist 154, $29-43$.

Meharg, A.A., Macnair, M.R., 1990. An altered phosphate uptake system in arsenate-tolerant Holcus lanatus L. New Phytologist 116, 29-35.

Meharg, A.A., Macnair, M.R., 1991. Uptake, accumulation and translocation of arsenate in arsenate-tolerant and non-tolerant Holcus lanatus L. New Phytologist 117, 225-231.

Meharg, A.A., Macnair, M.R., 1992. Suppression of the high affinity phosphate uptake system - a mechanism of arsenate tolerance in Holcus lanatus L. Journal of Experimental Botany 43, 519-524.

Phillips, J.M., Hayman, D.S., 1970. Improved procedures for clearing roots and staining parasitic and vesicular-arbuscular mycorrhizal fungi for rapid assessment of infection. Transactions of the British Mycological Society $55,158-161$

Rosen, B.P., 2002. Biochemistry of arsenic detoxification. FEBS Letters 529, 86-92.

Sharples, J.M., Meharg, A.A., Chambers, S.M., Cairney, J.W.G., 2000a. Evolution - symbiotic solution to arsenic contamination. Nature 404, 951-952.

Sharples, J.M., Meharg, A.A., Chambers, S.M., Cairney, J.W.G., 2000 b. Mechanism of arsenate resistance in the ericoid mycorrhizal fungus Hymenoscyphus ericae. Plant Physiology 124, 1327-1334.

Sharples, J.M., Meharg, A.A., Chambers, S.M., Cairney, J.W.G., 2001. Arsenate resistance in the ericoid mycorrhizal fungus Hymenoscyphus ericae. New Phytologist 151, 265-270.

Smith, S.E., Read, D.J. (Eds.), 1997. Mycorrhizal Symbiosis, second ed. Academic Press, San Diego, CA.

Smith, S.E., Smith, F.A., Jakobsen, I., 2003. Mycorrhizal fungi can dominate phosphate supply to plants irrespective of growth responses. Plant Physiology 133, 16-20.

Trotta, A., Falaschi, P., Cornara, L., Minganti, V., Fusconi, A., Drava, G., Berta, G., 2006. Arbuscular mycorrhizae increase the arsenic translocation 
factor in the As hyperaccumulating fern Pteris vittata L. Chemosphere 65, $74-81$.

Ultra, V.U., Tanaka, S., Sakurai, K., Iwasaki, K., 2007. Effects of arbuscular mycorrhiza and phosphorus application on arsenic toxicity in sunflower (Helianthus annuus L.) and on the transformation of arsenic in the rhizosphere. Plant and Soil 290, 29-41.
Willsky, G.R., Malamy, M.H., 1980a. Characterization of two genetically separable inorganic phosphate transport systems in Escherichia coli. Journal of Bacteriology 144, 356-365.

Willsky, G.R., Malamy, M.H., 1980b. Effect of arsenate on inorganic phosphate transport in Escherichia coli. Journal of Bacteriology 144, 366-374. 